Marketing in Asia Group

\title{
Antecedents of Chinese Consumer' Online Shopping Behaviour
}

\author{
Richard Asiedu \\ Faculty of Science, Technology, Engineering and Mathematics, International \\ University of Malaya-Wales (IUMW), Malaysia

\section{Francisca Nyarai Mapiye Dube} \\ International Business School Suzhou (IBSS), Xi'An Jiaotong-Liverpool University, \\ China
}

\begin{abstract}
The internet has become part and parcel of consumers' daily activities. One can simply buy anything online only with a click of a button and have products delivered right at their doorstep. This paper explores the antecedents of Chinese consumer behaviours towards online shopping. The quantitative research method was adopted for the study using data obtained from 208 Suzhou residents and analysed using Structural Equation Model (SEM) with Amos 23. The paper concludes that attitude is the sole predictor of online shopping behaviour. The results of the study further show that online shopping experience and social influence relate positively and significantly with the sentiment but price motion was not significant. Also, convenience has a positive significant relationship with attitude whiles perceived usefulness, but the ease of use was not significant. Finally, the results reveal that sentiment is not directly related to online shopping behaviour but indirectly related through attitude. Based on these findings, we provide important managerial implications and offer guidance to ecommerce platforms and online retailers.
\end{abstract}

Keywords: Online Shopping, Customers' Behaviour, Structural Equation Modelling 


\section{Introduction}

Online presence and activity have become of paramount importance in our daily lives. It is predicted that global e-commerce sales are expected to reach $\$ 4.2$ trillion USD in 2020 and reach more than $\$ 6.5$ trillion by 2023 (Winkler, 2020). More than 2.1 billion shoppers are expected to purchase goods and services online by 2021 (Winkler, 2020). China has the biggest online shopping market in the world with over 3.88 trillion RMB online shopping market transactions reached in 2015 (Miao, Lu \& Xie, 2017). It was revealed that about $80 \%$ of adults in China's biggest cities already shop online (The Economist, 2017). This shows that China has undoubtedly established itself as the world's biggest online market and related infrastructure. However, there are few pieces of research that have been done on online shopping behaviour compared to intention, especially in China. Prior studies show that online shopping research focused more on customer intention rather than behaviour (Kim, Lee, Hwang \& Yoo, 2016; Wei, Lee \& Shen, 2018; Wei, Wang, Zhu, Xue, \& Shen, 2018). For instance, Jalilvand and Samiei (2012) disclosed that online customer behaviour has received little attention in the literature compared with intentions. There is limited scholarly research on online shopping behaviour (Fogel \& Zachariah, 2017), therefore, there is a need for more research to be on online shopping behaviour. One of the reasons why testing of behaviour is better than intention is that intentions do not always translate into behaviour (Jalilvand \& Samiei, 2012) because it is believed that consumers may forestall wrongly the shopping context which distracts them from their intentions to purchase (Auger \& Devinney, 2007).

Similarly, Carrington, Neville, and Whitwell (2010) suggested that certain types of situations constrain the translation of intentions into behaviour, for instance, the distraction in the shopping context could make a person forget his/her intentions. Ajzen (1990) also asserts that a lack of ability to perform certain behaviours can prevent an individual's intention to lead to behaviour. Therefore, to bridge this gap, this paper intends to empirically examine antecedents of Chinese consumers' behaviour towards online shopping using the Unified Theory of Acceptance and Use of Technology (UTAUT) and data from residents of Suzhou. The study chose Suzhou which is of the second-tier cities in China as the study area because most past online shopping studies conducted in China focused on first-tier cities such as Beijing, Shanghai, Fuzhou, and Guangzhou (Jun \& Jaafar, 2011). Even though most online marketers have focused their attention on capturing consumers in high-tier cities, but over 50 percent of digital consumers residing in lower-tier cities (Bu, Wang, Wang \& Zipser, 2019). There are differences in terms of growth and expansion of economies, consumer behaviour, income level, population size, consumer sophistication, infrastructure, talent pool, and business opportunity between first and other tier cities in China (Wang, Xia, \& Zhang, 2017; Xinhua, 2017). Therefore, Jun and Jaafar (2011) recommend that future researches on online shopping should not be focused on only the big cities but rather expand to different provinces of China. 


\section{Literature Review}

\section{Theoretical Framework}

The research used the Unified Theory of Acceptance and Use of Technology (UTAUT) as the theoretical foundation to analysed the factors affecting the online shoppers' buying behaviour. The UTAUT suggests performance expectancy (PE), effort expectancy (EE), social influence (SI), and facilitating conditions (FC) as the variables that influence the user behaviour (Venkatesh, Morris, Davis \& Davis, 2003). The reason for not using the Technology Acceptance Model (TAM) which is widely used for customer behaviour studies is that the TAM model lacks a diversity of variables that influence user behaviour and low explain-ability of variance in the user behaviour towards the use and acceptance a system or technology (Venkatesh et al., 2003). Rather the UTAUT model has 20 to $30 \%$ greater explanatory power than the TAM (Venkatesh et al., 2003). According to Venkatesh et al. (2003) and Steinke (2015), the UTAUT can explain about $70 \%$ of the variance in the behavioural intention to use and accept a system or technology. Notwithstanding, our final research model integrated three original constructs of TAM (attitude, perceived usefulness \& perceived ease of use), one original constructs of UTAUT (social influence), and four external variables that are essential to online shopping (convenience, online shopping experience, sentiment, and price promotion). The reason for adopting only the social influence construct of the UTAUT model is that two of its constructs (PE \& EE) are similar to the perceived usefulness (PU) and perceived ease of use (PEU) constructs of TAM. PE can be mapped to perceived usefulness (PU) whereas EE can be mapped to perceived ease of use (PEU) (Dwivedi, Rana, Chen \& Williams, 2011).

\section{Conceptual Model}

Based on the literature reviewed the following conceptual model was developed to be tested.

Figure 1: Proposed Conceptual Model for the Study

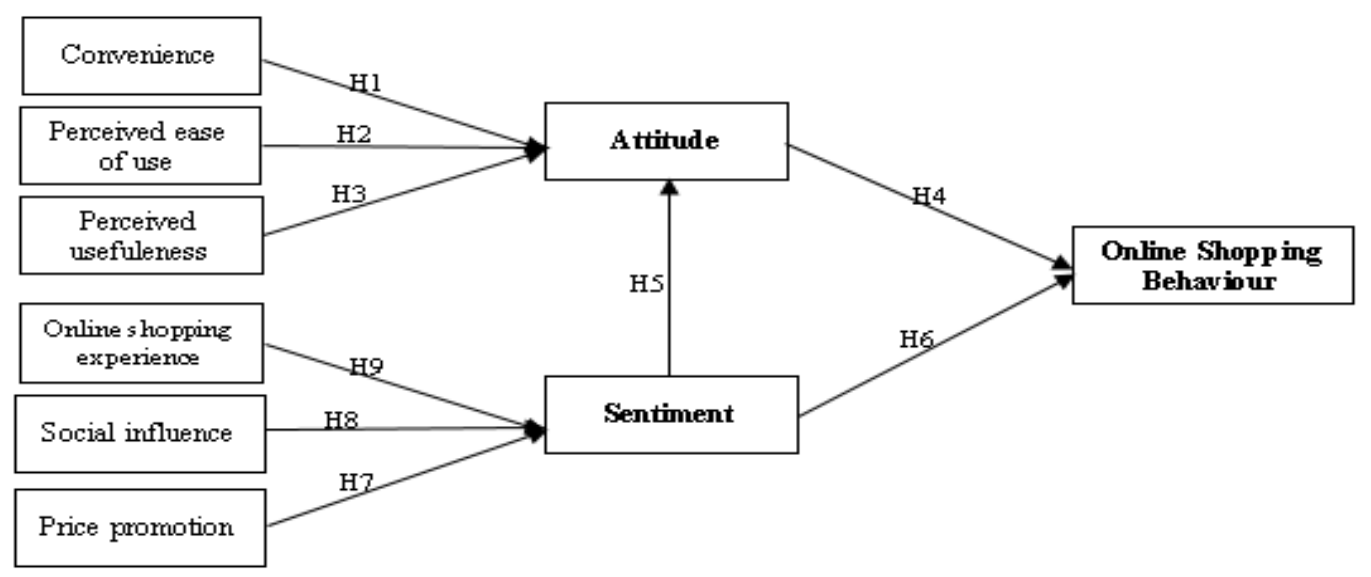




\section{Prior Empirical Research on the Antecedents of Consumers' Behaviour Towards Online Shopping}

\section{Convenience}

Online shopping convenience has become one of the primary impetus underlying customer inclinations to adopt online purchasing (Law et al., 2016). Customers' viewpoints on convenience can impact their willingness to buy products from online shops (Katawetawaraks \& Wang, 2011). Researches have revealed different reasons why convenience relates positively to customers' attitude towards online shopping. Dang, Tran, Nguyen, Le, Do, Nguyen, Nguyen, Nguyen, Mai, Tran, Ngo, Vu, Latkin, Zhang, and Ho (2018) found convenience as the most crucial factor that influenced consumers' attitude towards online purchases because convenience is one of the key concerns in online shopping culture of the participants. Also, shopping online helps them to achieve time efficiency. Similarly, Wei, Lee, and Shen (2018) revealed that consumers' ability to place orders at any time that is convenient to them, ability to compare different online stores and easy and convenient online payment system are some of the reasons why perceived convenience indirectly related with consumers' online purchase intentions. Another study conducted by Singh and Ajmani (2017) in the Southeast Asia context found that home delivery, time-saving and 24/7 availability, wide product varieties, discount, and multi-category of products available in one portal are factors contributing to the positive relationship between convenience and customers' behaviour towards shopping online. Therefore, the current study predicts that:

H1 There is a positive relationship between convenience and customer attitudes about online shopping.

\section{Perceived Ease of Use}

Perceive ease of use (PEU) is defined as the consumers' perceptions that online shopping facilitates the process of shopping (i.e., it reduces the effort and makes it easy to shop) (Pelaez, Chen \& Chen 2017). On the effect of PEU on consumers' attitudes towards online shopping, Lim and Ting (2012) revealed that the PEU of technological interfaces and tools on online shopping sites positively enhances the online shopper's attitude towards online shopping. Similarly, Singh, and Ajmani (2017) found the reason for the significant relationship between PEU and consumers' attitudes towards online shopping to include customer delight in the easiness to read and understand online shopping website contents. Changchit, Cutshall, Lonkani, Pholwan, and Pongwiritthon (2018) also confirmed that customers who find it easier to find products online, especially on shopping websites that have search functionality, and provide more detailed descriptions of the products than would typically be found on product packaging are likely to shop online. Additionally, Nguyen, Nguyen, Nguyen, Phan, Bui, and Moon (2019) confirmed that perceived ease of use had the greatest impact on attitude towards online shopping because consumers' attitudes are sturdily predicted by how easy it is to order and purchase 
products from retailers' websites. However, Suki and Suki (2011) and Djamasbi, Fruhling, and Loiacono (2009) interestingly found an insignificant relationship between perceived ease of use (PEU) and consumers' attitudes. They argued that ease of use may not be as important because certain user characteristics such as educational level may influence the acceptance behaviour (Djamasbi et al. 2009) which would make easy to use the system and would not require a lot of mental effort (Suki \& Suki, 2011). Another reason is the inherently different tasks performed by different information systems (Djamasbi et al. 2009). Therefore, the study posits that:

H2 There is a positive relationship between perceived ease of use and customer attitudes about online shopping.

\section{Perceived Usefulness}

Prior studies show that the more customers perceived online shopping to be useful the more likely they are to have a favourable attitude toward it. For instance, Lim and Ting (2012) found perceived usefulness to have a significant positive impact on customers' attitudes towards online shopping because consumers perceived that online shopping improves their shopping performance and productivity. Likewise, Phang and Ming (2018) uncovered that perceived usefulness of blogger's recommendation was found to related positively with consumer attitude towards online shopping due to the fact that such recommendations are considered a vital source of information for the consumers at the searching stage of their online shopping process. Wei, Lee, and Shen (2018) revealed that Chinese consumers need to have a strong perception of usefulness to make their online buying decisions because Chinese cultural values do not favour uncertainty and change. Similarly, Nguyen et al. (2019) indicate that perceived usefulness is a strong predictor of consumers' attitude towards online shopping, therefore, e-retailers should use communication programs that would make online shopping more time-saving, convenient, and effective and improve consumers' shopping performance and experience. A recent study by McLean, Osei-Frimpon, Wilson, and Pitardi (2020) found that perceived usefulness significantly influenced positive attitudes towards the website because the customers believe that having a live chat communication with an online travel representative was a good idea and a pleasant experience when using the website. Notwithstanding, Changchit et al. (2018) found no significant relationship between perceived usefulness and consumers' attitude towards shopping online. Similarly, Kanchanatanee, Suwanno, and Jarernvongrayab (2014) and Suki and Suki (2011) also found an insignificant relationship between perceived usefulness and consumers' attitude. Therefore, we predict that:

H3 There is a positive relationship between perceived usefulness and customer attitudes about online shopping. 


\section{Attitude}

Attitude describes how a consumer is likely to react either in a positive or negative way in response to an object, event, or incentive (Fishbein \& Ajzen,1975). Attitude is a complex construct with intellectual, affective, and behavioural components (Fishbein \& Ajzen, 1975). The intellectual component entails previous knowledge on a subject or an object. The affective components drawdown to an individual's likes' and dislikes, this forms personal attributes, but the behavioural component refers to the type of action an individual takes regarding a matter or towards an object (Fishbein \& Ajzen, 1975). This paper seeks to find out the action's consumers take towards online shopping and what influences the decisions to take these actions. Although attitude is argued to predict intention better than behaviour (Ajzena \& Fishbein, 1975), however, recent studies show that there is a direct link between attitude and behaviour (McSporran \& Cho, 2017; Akkaya, Akyol \& Şimşek, 2017). The reason for the positive impact of attitude on consumers' buying behaviour is upto-date, timely, and easily accessible information on products, easy accessibility to several product options and price comparison facilities (Akkaya et al., 2017), and perceived quality of products, trustworthiness, and price (McSporran \& Cho, 2017) are the reasons for customers' positive attitudes towards online shopping behaviour. Further, Hidalgo-Baz et al. (2017) revealed that because of the environmental benefits of organic products, and consumers' knowledge about organic products customers' attitudes related significantly positively with online purchase behaviours. Interestingly, Carvalho (2008) found no positive correlation between a positive attitude and higher purchase behaviour. Based on this, it is hypothesised that:

H4 There is a positive relationship between attitude and customer online shopping behaviour.

\section{Consumer Sentiment}

Cambridge Dictionary (2020) defines sentiment as 'a thought, opinion, or idea based on a feeling about a situation, or a way of thinking about something.' A sentiment is described as people's opinions, feelings, evaluations, and ratings for assets such as products, services, organizations, individuals, subjects, activities, titles, and qualifications (Awrahman \& Alatas, 2017). NetOwl's (2018) sentiment analysis findings reveal that a significant $97 \%$ of online shoppers report that customer reviews impacted their decision to buy a product or service. In addition, a recent study by Phang \& Goh (2019) revealed that when consumers develop a sense of attachment and a degree of consistency with a particular brand like to a person, they are likely to have positive behaviour towards the use of such products bearing such a brand. Positive sentiment brings a better attitude towards online shopping behaviour because Chinese customers' overall sentiment in relation to both overall satisfaction and product-level satisfaction was high (Zhou, Xia \& Zhang, 2016). Gillitzer and Prasad (2016) found that consumer sentiment influences actual consumer behaviour and has predictive power for future movements in consumption. Similarly, Shayaa, Al-Garadi, Piprani, Ashraf \& Sulaiman (2017) found a very small correlation between the sentiment analysis scores of the social media big data posts and the online purchase of computers and phones. Although the effect size is almost negligible it is believed that 
social media users tend to be more truthful when they are expressing their opinions through social media platforms which lead customers who read reviews before online buying decisions develop favourable attitudes and behaviour towards online shopping. Consistently, another recent study also indicates that there is a positive effect of online reviews on the purchase intentions of customers (Sharma, Sharma, Chouhan, Nage, \& Arun, 2019). On the contrary, Floh et al. (2013) found a significantly negative relationship between negative sentiment and attitude towards online shopping and their purchasing decision. Therefore, the following hypotheses are proposed.

H5 There is a positive relationship between customer sentiment and online shopping through attitudes.

H6 There is a positive relationship between customer sentiment and customers' online shopping behaviour.

\section{The Relationships between Price Promotion, Social Influence and Online Shopping Experience and Customer Sentiment}

The findings of Nagar's (2017) suggest that e-commerce retailers should increasingly move towards a multi-category purchase model as a way to boost consumer purchasing behaviour. Bedi, Kaur, and Lal (2017) concluded in their study that website interactivity and online experience influence the attitude and consumers' online shopping behaviour because of the favourable website visual design, website interactivity, website privacy and security and how easy it was to use the online shopping websites. Similarly, Teh, Pak, Rayson, and Piao's (2015)'s results show a significant relationship between online shopping experience and customer sentiment which demonstrated by the positive comment given by customers after online shopping. KPMG (2017) reports that the ability to compare prices, better prices, the reasons consumers shop online instead of stores. Price promotion and income expectations are positively linked with consumer sentiment (Oduh, Oduh \& Onyia, 2012) because customers believe and expect a future rise in the prices of the products after the promotion period. Similarly, Oduh, Oduh, and Ekeocha's (2012) empirical study showed a positive relationship between price promotion and consumer sentiment. The reason is that like most developing countries, the pattern of consumption in Nigeria is skewed towards food which accounts for a higher proportion of the total expenditure. Chun (2016) also found that speculation expecting an increase in price, leads customers to buy their products at the promotion price; therefore, a positive relationship between price and consumer sentiment. In addition, Zhang, Deng, and Xu (2017) revealed that consumer sentiment plays a mediating role in the significant impact price promotion had on consumers' purchasing intention. Therefore, the following hypotheses are proposed.

H7 There is a positive relationship between low price promotions by online retailers and customer sentiment. 
H8 There is a positive relationship between social influence and customer sentiment.

H9 There is a positive relationship between online shopping experience and customer sentiment.

\section{Research Method}

\section{Research Approach}

The study used a quantitative research approach to examine the online shopping behaviour of consumers in China. The quantitative research paradigm has been widely used by several researchers (Wei et al., 2018; Singh \& Ajmani, 2017; Nagar, 2017; Bedi, Kaur \& Lal, 2017) in previous studies on consumers' online shopping behaviour. The current study was guided by positivism beliefs. In positivism, knowledge is obtained from empirical testing (Richardson, 2012). Due to the exploratory nature of the research objectives, the study adopted a correlational research design and Structural Equation Modelling (Byrne, 2016) to determine the relationship between antecedents and online shopping behaviour. Correlational research is a type of non-experimental research on which the researcher measures two variables and assesses the statistical relationship between them with little or no effort to control extraneous variables.

\section{Sampling and Data Collection}

The target population of the study was the residents of Suzhou, China. The rationale for choosing the residents of Suzhou is that this city is one of the second tiers cities in China. Different city tiers imply different consumer behaviours, income levels, and business opportunities. According to Xinhua (2018), cities in different tiers reflect differences in consumer behaviour, income level, population size, consumer sophistication, infrastructure, talent pool, and business opportunity. The tier-one cities are better off in all these areas than the others. Also, Suzhou has not received much attention yet in the literature in terms of online shopping research (Mapiye Dube, Asiedu \& Phiri, 2018). Since the study is exploratory in nature more precedent was given to include a second-tier city as there are differences between growth and expansion of economies between first and other tier cities in China (Wang et al., 2017). Past online shopping research has focused on first-tier cities such as Beijing, Shanghai, and Guangzhou and neglects other tier cities (Chen, Zheng, Zhang, \& Wag, 2017; Wang, Hao, Hou, Wetzstein, \& Wang, 2019). Therefore, data were collected through a survey questionnaire from residents living in Suzhou who have shopped online before.

A convenience sampling technique was used for selecting the participants for the study. A convenience sampling technique is a type of nonprobability where members of the target population that meet certain practical criteria, such as easy accessibility, geographical proximity, availability at a given time, or the willingness to participate are included for the purpose of the study (Etikan, Musa, \& Alkassim, 2016). The questions on the questionnaire were structured using the 5-point Likert scale format 
(with 5 = Strongly agree and $1=$ Strongly disagree). We obtained 208 valid questionnaires responses representing $59.4 \%$ out of a total of 350 questionnaires distributed. We used a sample size of 208 because Boomsma (1985) previously suggested a sample size of 100 or 200 as the minimum for SEMs. Also, G*Power 3.1.9.4 software was used to determine the minimum sample size for the study and the analysis results showed a minimum sample size of 74 is required. This supports that the sample size of 208 used for this research is acceptable for structural equation modelling (SEM) analysis.

\section{Measurement Development}

Multi-item scales are used to measure each of the constructs in the study. We generated items by reviewing existing literature online shopping. Items from existing scales were adapted to measure the variables of the study. Online Shopping Behaviour (OSB), Perceived Ease of Use (PEU), and Convenience (CON) were measured with four items each adapted from Ganguly et al. (2009) and Chen and Barns (2007). Examples, OSB1 "I have developed the habit of shopping online", PEU1 "I find interaction through online shopping websites clear understandable" and CON2 "Shopping Online allows me to save time". Perceived Usefulness (PU), Price Promotion (PP), Social Influence, (SI), Attitude (ATT), and Sentiment (SEN) were measured with the three items taken from Clemes et al (2014), Venkatesh et al (2012) (Modified). Examples are PU1 "The online system makes it easy to find the content required", PP1 "I always compare prices between different brands before I choose, when I shop online", SI1 "My Friends encourage me to shop online", ATT1 "I prefer to buy from an online shopping website that provides me with quality of information" and SEN1 "Is the current economic situation in China good". Online Shopping Experience (OSE) was measured with the five items previously used by MichaudTrévina and Stenger (2014) and Rose, Clarck, Samouel, and Hair (2012). For instance, OSE1 is "I am satisfied with the speed of delivery for online shops". In total, 32 items were developed to measure the constructs in our model. All items were anchored with five-point Likert scales from strongly disagree to strongly agree.

\section{Findings of the Study}

\section{Demographic Profile of Respondents}

The analysis of the respondents' profile indicates that majority $51.9 \%$ of the respondents are male and $48.1 \%$ are females. Also, $75 \%$ of them are 19-24 years old, $35.1 \%$ indicated that they spend 3000-3999 RMB per month. Most of the respondents $(42.3 \%)$ are students and spend less than 3 hours of online shopping per week. Majority of them (78.4\%) shop online several times per week through mobile devices (52\%). Clothes $(34.1 \%)$ were the products the respondents purchased most online. Finally, Taobao (62\%) was ranked the respondents' most favoured online shopping website. 


\section{Reliability and Validity Analysis}

Descriptive statistic methods and exploratory factor analysis (EFA) using SPSS 23 and confirmatory factor analysis (CFA), and structural equation modeling using AMOS 23 were used to determine the validity and reliability of the model and its associated constructs. First, Harman's single factor test results show 31.936\% which means that there was no concern for common method variance (CMV) in this study (Podsakoff, MacKenzie, Lee \& Podsakoff, 2003). The findings presented in Tables 1, 2,3 , and 4 show that there were no validity and reliability issues in the data because all the loadings and constructs met the recommended reliability and validity criteria (Henseler, Ringle, \& Sarstedt, 2015). Regarding indicator reliability, construct to items loading are above the recommended threshold of 0.70 , except for some few items that are between 0.6 and 0.7, which is a range also considered acceptable for exploratory research (Hu \& Bentler, 1999). Also, the composite reliability (CR) and Cronbach's Alpha of all the constructs are larger than acceptable criteria of 0.70 (George \& Mallery, 2003). Convergent validity test results indicate that all the AVEs are either equal to or larger than the shared variances between all pairs of factors in the model. The lowest value is 0.50 which is equal to the acceptance criteria.

Table 1: Measurement Development/ Measures Analysis

\begin{tabular}{|c|c|c|c|c|c|}
\hline Constructs & Indicator & Loading & $\begin{array}{l}\text { Composite } \\
\text { reliability }\end{array}$ & $\begin{array}{c}\text { Cronbach's } \\
\text { Alpha }\end{array}$ & $\mathbf{A V E}^{1}$ \\
\hline \multirow[t]{3}{*}{ Attitude } & ATT1 & .72 & \multirow[t]{3}{*}{0.81} & \multirow[t]{3}{*}{0.71} & \multirow[t]{3}{*}{0.60} \\
\hline & ATT2 & .74 & & & \\
\hline & ATT3 & .85 & & & \\
\hline \multirow[t]{4}{*}{ Convenience } & CON1 & .70 & \multirow[t]{4}{*}{0.78} & \multirow[t]{4}{*}{0.83} & \multirow[t]{4}{*}{0.50} \\
\hline & CON2 & .62 & & & \\
\hline & CON3 & .70 & & & \\
\hline & CON4 & .74 & & & \\
\hline \multirow[t]{3}{*}{ Perceived usefulness } & PU1 & .63 & \multirow[t]{3}{*}{0.72} & \multirow[t]{3}{*}{0.71} & \multirow[t]{3}{*}{0.50} \\
\hline & PU2 & .70 & & & \\
\hline & PU3 & .70 & & & \\
\hline \multirow[t]{4}{*}{ Perceived ease of use } & PEU1 & .71 & \multirow[t]{4}{*}{0.80} & \multirow[t]{4}{*}{0.82} & \multirow[t]{4}{*}{0.50} \\
\hline & PEU2 & .63 & & & \\
\hline & PEU3 & .74 & & & \\
\hline & PEU4 & .75 & & & \\
\hline \multirow[t]{5}{*}{ Online experience } & OSE1 & .70 & \multirow[t]{5}{*}{0.81} & \multirow[t]{5}{*}{0.87} & \multirow[t]{5}{*}{0.50} \\
\hline & OSE2 & .70 & & & \\
\hline & OSE3 & .63 & & & \\
\hline & OSE4 & .71 & & & \\
\hline & OSE5 & .63 & & & \\
\hline \multirow[t]{3}{*}{ Price promotion } & PP1 & .75 & \multirow[t]{3}{*}{0.76} & \multirow[t]{3}{*}{0.75} & \multirow[t]{3}{*}{0.51} \\
\hline & PP2 & .70 & & & \\
\hline & PP3 & .70 & & & \\
\hline \multirow[t]{3}{*}{ Social influence } & SI1 & .68 & \multirow[t]{3}{*}{0.74} & \multirow[t]{3}{*}{0.69} & \multirow[t]{3}{*}{0.50} \\
\hline & SI2 & .70 & & & \\
\hline & SI3 & .70 & & & \\
\hline \multirow[t]{3}{*}{ Sentiment } & SEN1 & .66 & \multirow[t]{3}{*}{0.70} & 0.70 & 0.50 \\
\hline & SEN2 & .64 & & & \\
\hline & SEN3 & .68 & & & \\
\hline Online shopping Behaviour & OSB1 & .79 & 0.83 & 0.80 & 0.50 \\
\hline & OSB2 & .76 & & & \\
\hline & OSB3 & .80 & & & \\
\hline & OSB4 & .62 & & & \\
\hline
\end{tabular}


Tables 2 and 3 illustrate the discriminant validity analyses. As shown in Table 2, the diagonal values (in bold) indicate the square root of the AVEs for the nine (9) constructs in this study whiles the rows and columns represent the correlations of each pair of constructs.

Table 2: Means, Standard Deviations and Intercorrelation Matrix Analysis

\begin{tabular}{|c|c|c|c|c|c|c|c|c|c|c|c|c|}
\hline Variable & Mean & SD & $\mathbf{N}$ & 1 & 2 & 3 & 4 & 5 & 6 & 7 & 8 & 9 \\
\hline 1. Convenience & 16.72 & 3.07 & 208 & 0.71 & & & & & & & & \\
\hline 2. Perceived usefulness & 12.15 & 4.70 & 208 & $0.37 * *$ & 0.71 & & & & & & & \\
\hline 3. Perceived ease of use & 15.04 & 3.04 & 208 & $0.64 *$ & $0.42 * *$ & 0.71 & & & & & & \\
\hline 4.Online shopping experience & 19.50 & 3.99 & 208 & $0.60 * *$ & $0.31 * *$ & $0.70 * *$ & 0.71 & & & & & \\
\hline 5. Price promotion & 6.25 & 2.64 & 208 & 0.00 & -0.05 & -0.03 & -.03 & 0.71 & & & & \\
\hline 6. Social Influence & 10.97 & 2.71 & 208 & 0.00 & 0.07 & 0.03 & -.07 & $0.46^{* *}$ & 0.72 & & & \\
\hline 7. Attitude & 11.23 & 2.09 & 208 & $0.50 * *$ & $0.19 * *$ & $0.30 * *$ & $.23^{* *}$ & 0.04 & $0.23 * *$ & 0.77 & & \\
\hline 8. Sentiment & 14.74 & 2.63 & 208 & $0.25 * *$ & 0.10 & $0.36 * *$ & $.45^{* *}$ & $0.17^{*}$ & $0.70^{*}$ & $0.31 * *$ & 0.71 & \\
\hline 9 Online shopping behaviour & 42.89 & 7.51 & 208 & 0.06 & 0.04 & 0.07 & .04 & $-0.23 * *$ & -0.13 & $0.17 *$ & .07 & 0.71 \\
\hline
\end{tabular}

The discriminant validity analysis results presented in Table 2 show that all of the constructs are distinct from each other, and all of the other correlations had values that are less than the square root of the AVE for each individual construct. The Heterotrait-Monotrait (HTMT) analysis results (Table 3) also reveal that all the values were less than 0.85 and met the recommended value for discriminant validity (Henseler et al., 2015). These results provide strong support for the discriminant validity of the constructs (Henseler et al., 2015).

Table 3: HTMT Analysis

\begin{tabular}{lccccccccc}
\hline & ATT & CON & PU & PEU & OSE & PP & SI & SEN & OSB \\
\hline ATT & & & & & & & & & \\
CON & 0.17 & & & & & & & & \\
PU & 0.02 & 0.83 & & & & & & & \\
PEU & 0.04 & 0.78 & 0.84 & & & & & & \\
OSE & 0.11 & 0.70 & 0.70 & 0.82 & & & & & \\
PP & 0.04 & 0.63 & 0.71 & 0.76 & 0.75 & & & & \\
SI & 0.02 & 0.57 & 0.68 & 0.66 & 0.69 & 0.72 & & & \\
SEN & 0.83 & 0.11 & 0.05 & 0.02 & 0.12 & 0.03 & 0.03 & & \\
OSB & 0.11 & 0.57 & 0.58 & 0.52 & 0.50 & 0.43 & 0.69 & 0.13 & \\
\hline
\end{tabular}

\section{Confirmatory Factor Analysis}

This study conducted a confirmatory factor analysis to assess the measurement model's overall fit and validity of the constructs. Research indicates that a model is considered to be fit when the Comparative Fit Index (CFI) exceeds 0.90, TuckerLewis Index (TLI) exceeds 0.90, Chi-square with the degree of freedom $\left(\chi^{2} / \mathrm{df}\right)$ ) is less than 3, Root Mean Square Error of Approximation (RMSEA) is less than 0.08 and Standardized Root Mean Square Residual (SRMR) is less than 0.08 (Hu, \& Bentler, 1999; Hair, Black, Babin, Anderson, \& Tatham, 2010; Fornell \& Larcker, 1981). The results show that the measurement model is of a good fit for the study with 
the following values: $\mathrm{CFI}=0.917, \mathrm{TLI}=0.962, \chi^{2} / \mathrm{df}=0.786$, $\mathrm{RMSEA}=0.057$, and $\mathrm{SRMR}=0.053$.

\section{Structural Model and Hypothesis Tests}

The findings of the analysis also reveal that the structural model is of a good fit for the study with the following values: $\mathrm{CFI}=0.996$, TLI $=0.992, \chi^{2} / \mathrm{df}=0.386$, RMSEA $=0.018$, and SRMR $=0.032$. As illustrated in Fig. 2 and Table 6, the SEM results indicate that all hypotheses except $\mathrm{H} 2, \mathrm{H} 3, \mathrm{H} 6$, and $\mathrm{H} 7$ were supported. Convenience motivated consumers to develop a positive attitude towards online shopping (H1, $\beta=$ $0.499, \mathrm{SE}=0.053, \mathrm{p}<.001)$. Participants in the study indicated that they were influenced socially to have a positive sentiment towards online shopping ( $\mathrm{H} 8, \beta=$ $0.148, \mathrm{SE}=0.065, \mathrm{p}<.05)$.

Figure 2: Research model with standardized path coefficients $\left({ }^{*} p<.05, \& * * p<.001\right)$

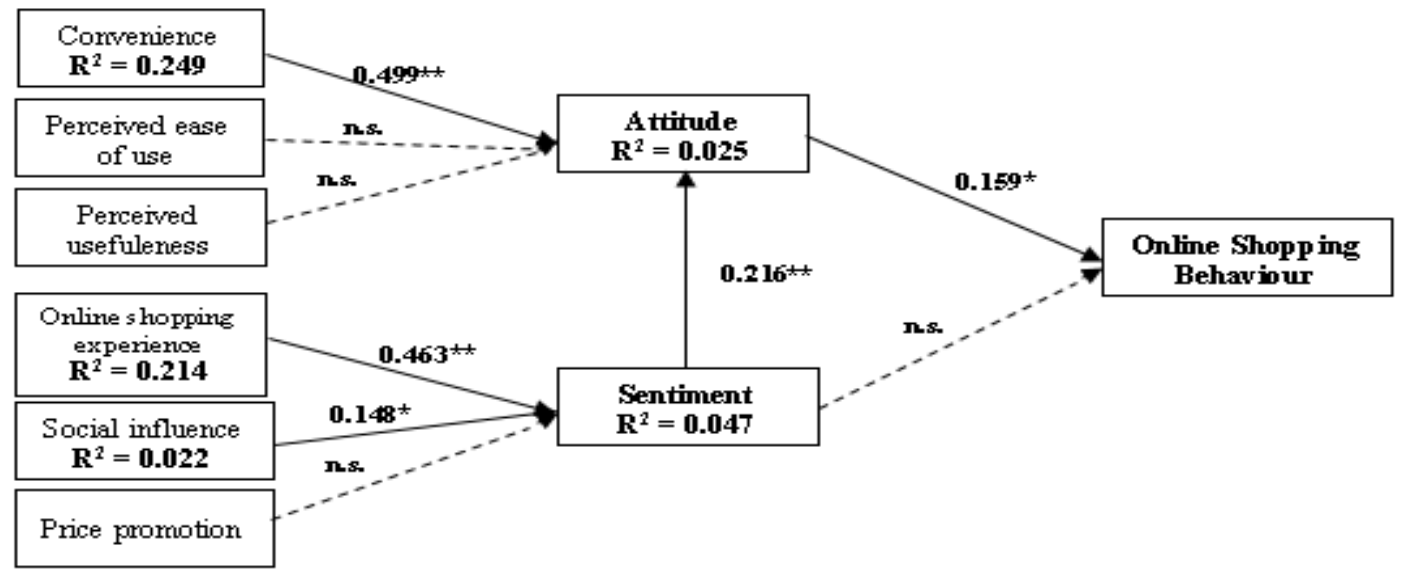

Respondents with a good previous online shopping experience had a more positive sentiment towards online shopping behaviour. (H9, $\beta=0.463, \mathrm{SE}=0.039, \mathrm{p}<.001$ ). Again, sentiment related positively and significantly with online shopping behaviour through attitude $(\mathrm{H} 5, \beta=0.216, \mathrm{SE}=0.050, \mathrm{p}<.001)$. Finally, respondents revealed that their attitude related significantly and positively with online shopping behaviour $(\mathrm{H} 4, \beta=0.024, \mathrm{SE}=0.206, \mathrm{p}<.05)$.

Table 6: Summary of Hypothesis Tests

\begin{tabular}{|l|l|l|l|}
\hline Hypotheses & $\begin{array}{l}\text { Standardized Path } \\
\text { Coefficient }\end{array}$ & Standard Errors & Results \\
\hline H1. CON $\Rightarrow$ ATT & $0.499^{* *}$ & 0.053 & Supported \\
\hline H2. PEU $\Rightarrow$ ATT & 0.030 & 0.029 & Not supported \\
\hline H3. PU $\Rightarrow$ ATT & 0.110 & 0.056 & Not supported \\
\hline H4. ATT $\Rightarrow$ OSB & $0.159^{*}$ & 0.258 & Supported \\
\hline H5. SEN $\Rightarrow$ ATT & $0.216^{* *}$ & 0.050 & Supported \\
\hline H6. SEN $\Rightarrow$ OSB & 0.024 & 0.206 & Not supported \\
\hline H7. PP $\Rightarrow$ SEN & 0.118 & 0.067 & Not supported \\
\hline H8. SI $\Rightarrow$ SEN & $0.148^{*}$ & 0.065 & Supported \\
\hline H9. OSE $\Rightarrow$ SEN & $0.463^{* *}$ & 0.039 & Supported \\
\hline
\end{tabular}

$* p<.05, \& * * p<.001$

Notes: $C O N=$ Convenience, $P U=$ Perceived usefulness, $P E U=$ Perceived ease of use, $P P=$ Price promotion, $S I=$ Social influence, $O S E=$ Online shopping experience, $S E N=$ Sentiment, $A T T=$ Attitude and $O S B=$ Online shopping behaviour. 


\section{Discussion}

This study explores factors that influence customers' behaviour towards online shopping. Convenience, social influence, online shopping experience, sentiment, and attitude were found to influence customers' behaviour towards online shopping either directly or indirectly. Convenience and sentiment were found to have a significant positive relationship with attitude. Social influence and online experience were also found to have a significant positive relationship with the sentiment. Finally, the attitude was found to relate positively and significantly with online shopping behaviour. The results establish that attitude is the sole predictor of customers' online shopping behaviour. On the contrary to the hypotheses stated in this study, perceived usefulness and EOU and price promotion respectively were found not to relate significantly with attitude and sentiment. Also, the sentiment was found to have a significant positive relationship with online shopping behaviour through attitude.

These findings are consistent with previous literature (Dang et al., 2018; Wei et al., 2018; Singh \& Ajmani, 2017). They found that convenience is more strongly and positively associated with customers' attitudes towards online shopping behaviour because customers are able to get wide product varieties, do timely transactions, save time, do not join long queues, pay with ease, shopping from their homes and anywhere. On the linkage between attitude and online shopping behaviour, our results confirm the findings of Lim and Ting (2012), Singh and Ajmani (2017), Changchit et al. (2018), and Nguyen et al. (2019). For instance, Changchit et al. (2018) and Nguyen et al. (2019) found that customers develop a positive attitude towards online shopping because it is easier for them to find and compare products online. The findings on the linkage between online shopping experience and customers' sentiment to online shopping are also found to be consistent with past studies (Bedi et al., 2017; Teh et al., 2015) Also, on the relationship between social influence and customer sentiment towards online shopping behaviour, the findings are consistent with the findings of Lee, Shi, Cheung, Lim, and Sia (2011).

However, unlike previous studies (Singh \& Ajmani, 2017; Pelaez et al., 2017; Changchit et al., 2018; Nguyen et al., 2019) that found a significant relationship between perceived ease of use (PEU) and consumers' attitude towards online shopping, our results show an insignificant relationship between them. However, this result is in line with the findings of Suki and Suki (2011) and Djamasbi et al. (2009) who found that perceived ease of use (PEU) had an insignificant impact on consumers' attitudes towards behaviour. The result implies that although perceived ease of use and users' attitude influence customer online shopping behaviour but the effect size is negligible. Our results also show an insignificant relationship between perceived usefulness (PE) and customer attitude (ATT) towards online shopping. This result contradicts the following prior studies (Lim \& Ting, 2012; Wei et al., 2018; Nguyen et al., 2019). However, our finding supports a recent study conducted by Changchit et al. (2018), which reported no significant relationship between perceived usefulness consumers' attitudes towards online shopping. Similarly, Kanchanatanee, Suwanno, and Jarernvongrayab (2014) found that perceived usefulness had no significant direct effect on attitude toward using E-Marketing within the three southern border provinces of Thailand. 
Although it is difficult to explain the unsupported outcome of hypotheses $\mathrm{H} 2$ and $\mathrm{H} 3$ rather we can offer some explanations. These findings do not necessarily or merely contradict the TAM theory but suggest that further extension of the model is needed to measure the online shopping behaviour of the second-tier cities in China. Also, in the context of this study, the respondents might not have perceived the influence of ease of use and usefulness on their attitude because of their rich experience in information communication technology and how convenient shopping online is to them. Finally, our results do not support the assumption that price promotion will influence customer sentiment. This finding is in line with Lee and Chen Yu (2018) who also failed to find a significant relationship between promotion and sentiment. The reason is that online shoppers form positive or negative sentiment towards a particular product or brand based on the reviews and e-word of mouth (E-WOM) they read online. Therefore, irrespective of the amount of promotion the retailers may do, it will not have any significant effect on the shoppers' sentiment if they have already read negative reviews and comments online.

\section{Research Implications}

The results reported in this study identify several managerial contributions for a better understanding of the factors of customer online shopping behaviour. First of all, the online shopping experience is very pivotal thus, marketers can devise strategies and modify a customer's online interaction to enhance the experience. E-retailors and marketers who are interested in increasing purchase and repurchase intentions of consumers to shop online, the antecedents mentioned above may be used to help in guiding marketing strategies and segmentation of online shoppers for the benefit of businesses and to increase customer loyalty. Secondly, convenience is a significant variable and this suggests that online retailers need to always work on improving their e-commerce websites and applications to make it more convenient and easier to use for their customers. Furthermore, customers are attracted to technology that can provide them convenience through saving time and effort. Thus, the website must be user-friendly and be able to process the customer's request as quickly as possible. In return, this will enable customers to complete a transaction quickly, which is both beneficial to the customer.

In terms of customer sentiment, our results show an indirect relationship between customer sentiment and online shopping behaviour through customer attitude. This suggests that the feeling of the customers and their feedback after online purchases affect their attitudes towards online shopping which alter their behaviour. This can be resolved by practicing effective sentiment analysis to gather customers' opinions, emotions, frustrations, or joy from blogs, reviews, social media posts, to analyse customer attitudes towards online shopping websites and products sold there. Emarketers need to take proactive actions to address and manage post-purchase dissatisfaction of customers to motivate them to continue to shop online and also to encourage satisfied customers to continue to give a positive word of mouth about the company and its products to family and friends or anyone to shop online. Finally, the paper concludes that attitude is the sole direct predictor of online shopping behaviour. Theoretically, this study offers some implications. First, we proposed a model that is appropriate for analysing consumers' online shopping behaviour by integrating TAM and UTAUT theories. The findings have proven this study to be one of the few studies 
that have merged the TAM and UTAUT theories to successfully predict online shopping behaviour. Also, the study contributes to the understanding of online shopping behaviour by considering consumer sentiment and individual spending excluding the household as a whole and how consumer sentiment has an impact on the buying behaviour of customers through attitude. Another theoretical implication of this study is that since social influence and online shopping experience are key determinants of online shopping behaviour through sentiment and attitude, online retailers must improve their complaint and customer relations management and sentiment analysis to have a better chance to enhance their customers' behaviour.

\section{Limitations, Future Research Direction, and Conclusion}

In spite of the practical implications and the theoretical contributions that this study makes to the online shopping literature, the study has some limitations. First, the study relied on 208 respondents in Suzhou, it is, therefore, suggesting that future studies should be extended to cover a large population. Thus, the context will only apply to this country and area. It may vary across other countries due to cultural differences, acceptance of technology, and many other factors. Although the use of this group of participants contributes to the literature on factors affecting customer online shopping behaviour, future studies can collect data from a similar sample in a different context. The study suggests that it might be of interest to identify and describe user clusters to see if there is a difference in behaviour between mobile shoppers and desktop shoppers in terms of social influence and past experience. Additionally, this study suggests that in the future, our new model should be tested and verified with more sample data via mixed methods to determine the relationships between the factors and consumers' online shopping behaviour. Furthermore, future studies need to incorporate other relevant variables such as habits, motivation, and security, etc. to predict online shoppers' buying behaviour.

\section{Implications for Asian Business Context}

The findings of the study will surely have a profound impact on how e-retailers will effectively manage the consumers' behaviour towards online shopping in Asia. The results of this study imply that attitude toward online shopping behaviour is strongly related to convenience and consumer sentiment. As the findings evidently proved that consumer attitude which is being influenced by convenience and sentiment is the major factor affecting online shopping behaviour, this could well be a precursor to improved and creative online services, and innovative online shopping websites that are attractive to shoppers from all over Asia. Especially, in this time of COVID-19 pandemic, Asians and of course the people around the world only secured means of shopping is online. Therefore, online shopping companies need to enhance their services to attract more customers and also positively assist their current customers to improve their attitudes and behaviour toward online shopping. Ease transaction process and timely delivery need to be encouraged. 
One other important revelation of this study is the indirect effect of consumer sentiment on online shopping behaviour. The findings confirmed that consumer sentiment plays a significant role in driving positive online shopping behaviour. Given the evidence that many online shoppers consult families and friends, current customers' experiences about products and online review comment before making the decision to shop online, the implication is that it is about time online shopping companies in China and Asia make more investment in sentiment analysis technologies to better understand consumers' preferences and behaviour and how best they want to be served. It will also help to provide the necessary and timely feedback to customers' complaints via social media platforms and other means of communication and also improve their services to the tune of the consumer preference. The business should pay critical attention to customer reviews on both their website and mobile apps because they are also a very important source of information like formal organisational marketing results that can help the businesses to improve their customers' online shopping behaviours.

In addition, although research indicates that the South East Asian consumers are comparatively young (60\% of the population are less than 35 years old) (see, Nielson report, 2019), which means that they are more likely to shop online than traditional stores. However, the question is, 'Is that really the case?'. Therefore, Asian Businesses that sell its products online should consider ways to reduce the negative aspects of the online shopping process that demotivate many of these young consumers who might be still shopping in the traditional stores in order to improve their experience by developing a reliable and safe website, an appealing and usable website, providing online service, and offering more options in terms of products and payment systems to attract many of these consumers. furthermore, because the results of the study revealed that peoples' decisions to shop online are being influenced by their friends and family and even comments on social media, it is incumbent upon Asian Businesses to enhance their online business integrity, and reputation in order to attract and maintain their customers.

Finally, most of the time people shop online because it is quick, easy, convenient and they do not have to leave their homes and go join long queues in shops. However, sometimes customers complain that the products they bought online are not delivered at all, or go passed the 30 days of the supply date (expected day of delivery). Some also even receive items that are significantly different in terms of colour, size, shape, etc. from the seller's original description on the seller's website. Therefore, the study recommends that online shopping companies in Asia should deliver what they promise to deliver in order to improve customers' attitudes towards online shopping behaviour especially in this age where online shopping is the safest means of shopping due to the kind of disruption caused by the Covid-19 pandemic.

\section{Acknowledgement}

This paper was presented at the 2018 MAG Scholar Conference in Business, Marketing, and Tourism (AICBMM-2016), held in Citadines Uplands Kuching, Sarawak, Malaysia, 22nd - 25th June 2018. The authors thank the conference participants for their comments on the paper. 


\section{References}

Akkaya, D. T., Akyol, A., \& Şimşek, G. G., (2017), "The effect of consumer perceptions on their attitude, behaviour, and purchase intention in social media advertising", Marmara Üniversitesi İktisadi ve İdari Bilimler Dergisi, vol. 39, no. 1, pp. 361-388.

Awrahman, B., \& Alatas, B., (2017), "Sentiment analysis and opinion mining within social networks using Konstanz information miner", Journal of Telecommunication, Electronic and Computer Engineering, vol. 9, no. 1, pp. 15-22.

Bagga, T., \& Bhatt, M., (2013), "A study of intrinsic and extrinsic factors influencing consumer buying behaviour online", Asia-Pacific Journal of Management Research and Innovation, vol. 9, no. 1, pp. 77-90.

Beauchamp, M. B., \& Ponder, N., (2010), "Perceptions of retail convenience for in-store and online shoppers", The Marketing Management Journal, vol. 20, no. 1, pp. 49-65.

Bedi, S. S., Kaur, S., \& Lal, A. K., (2017), "Understanding web experience and perceived web enjoyment as antecedents of online purchase intention", Global Business Review, vol. 18 , no. 2 , pp. $465-477$.

Boomsma, A., (1985), "Nonconvergence, improper solutions, and starting values in LISREL maximum likelihood estimation", Psychometrika, vol. 50, pp. 229-242.

Byrne, B. M., (2016), Structural equation modelling with AMOS: Basic concepts, applications, and programming, Routledge, London.

Bu, L., Wang, J., Wang, K. W., \& Zipser, D., (2019), "China digital consumer trends 2019: Discovering the next wave of growth", Retrieved from www.mckinsey.com/digital china.

Cambridge Dictionary, (2020), "Sentiment", Retrieved from https://dictionary.cambridge.org /dictionary/english/sentiment

Changchit, C., Cutshall, R., Lonkani, R., Pholwan, K., \& Pongwiritthon, R., (2018), "Determinants of online shopping influencing Thai consumer's buying choices", Journal of Internet Commerce, vol. 18, no. 1, pp. 1-23.

Chen, Y. H., \& Barnes, S., (2007), "Initial trust and online buyer behaviour", Industrial Management and Data Systems, vol. 107, no. 1, pp. 21-36.

Chen, J., Zheng, Q., Zhang, R. W., \& Wag, H. H., (2017), "Chinese preference for online grocery shopping: Shopping for convenience, quality, or price?", Agricultural and Applied Economics Association Annual Meetings, Chicago.

Chun, H., (2016), "A study on the impact of changes in consumer sentiment on the housing market in Korea", International Journal of Urban Sciences, vol. 21, no. 2, pp. 129-146.

Clemes, M. D., Gan, C., \& Zhang, J., (2014), "An empirical analysis of online shopping adoption in Beijing, China", Journal of Retailing and Consumer Services, vol. 21, no. 3, pp.364-375.

Dang, K. A., Tran, B. X., Nguyen, C., T., Le, H. T., Do, H. T., Nguyen, H. D., Nguyen, L. H., Nguyen, T. H., Mai, H. T., Tran, T. D., Ngo, C., Vu, T. T. M., Latkin, C. A., Zhang, M. W. B., Ho, R. C. M., (2018), "Consumer preference and attitude regarding online food products in Hanoi, Vietnam", International Journal of Environmental Research and Public Health, vol. 15, no. 5, pp. 1-12.

Djamasbi, S., Fruhling, A. L., \& Loiacono, E. T., (2009), "The influence of affect, attitude, and usefulness in the acceptance of telemedicine systems", Journal of Information Technology Theory and Application, vol. 10, no. 1, pp. 1-38.

The Economist, (2017), "Online retail is booming in China", Retrieved from https://www.eco nomist.com/special-report/2017/10/26/online-retail-is-booming-in-china

Etikan, I., Musa, S. A., \& Alkassim, R. S., (2016), "Comparison of convenience sampling and purposive sampling", American Journal of Theoretical and Applied Statistics, vol. 5, no. 1, pp. 1-4.

Fishbein, M., \& Ajzen, I., (1975), Belief, attitude, intention, and behaviour: An introduction to theory and research, Addison-Wesley, Reading. 
Floh, A., Koller, M., \& Zauner, A., (2013), "Taking a deeper look at online reviews: The asymmetric effect of valence intensity on shopping behaviour", Journal of Marketing Management, vol. 29, no. 5/6, pp. 646-670.

Fogel, J., \& Zachariah, S., (2017), "Intentions to use the yelp review website and purchase behaviour after reading reviews", Journal of Theoretical and Applied Electronic Commerce Research, vol. 12, no. 1, pp. 53-67.

Fornell, C., \& Larcher, D. F., (1981), "Evaluating structural equation models with unobservable variables and measurement error", Journal of Marketing Research, vol. 18 , no. 1 , pp. 39-50.

Ganguly, B., Dash, S. B., \& Cyr, D., (2009), "Website characteristics, trust, and purchase intention in online stores - An empirical study in the Indian context", Journal of Information Science and Technology, vol. 6, no. 2, pp. 22-44.

George, D., \& Mallery, P., (2003), SPSS for Windows step by step: A simple guide and reference, Allyn \& Bacon, Boston.

Gillitzer, C., \& Prasad, N., (2015), "The effect of consumer sentiment on consumption: CrossSectional evidence from elections", American Economic Journal, vol. 10, no. 4, pp. 234-269.

Gugnani, R., \& Choudhary, A., (2017), "Web shopping adoption by female web browsers for apparel shopping in India", FIIB Business Review, vol. 6, no. 4, pp. 48-59.

Hair, J. F., Black, W. C., Babin, B. J., Anderson, R. E., \& Tatham, R. L., (2010), Multivariate data analysis, Pearson, London.

Hair, J. F., Hult, G. T. M., Ringle, C. M., \& Sarstedt, M., (2017), A primer on Partial Least Squares Structural Equation Modeling (PLS-SEM), Sage, Thousand Oaks.

Henseler, J., Ringle, C. M., \& Sarstedt, M., (2015), "A new criterion for assessing discriminant validity in variance-based structural equation modelling", Journal of the Academy of Marketing Science, vol. 43, no. 1, pp. 115-135.

Hidalgo-Baz, M., Martos-Partal, M., \& González-Benito, Ó., (2017), “Attitudes vs. purchase behaviours as experienced dissonance: The roles of knowledge and consumer orientations in organic market", Frontiers in Psychology, vol. 8, pp. 1-8.

Hu, L. T., \& Bentler, P. M., (1999), "Cut-off criteria for fit indexes in covariance structure analysis: Conventional criteria versus new alternatives", Structural Equation Modelling: A Multidisciplinary Journal, vol. 6, no. 1, pp.1 -55.

Jun, G., \& Jaafar, N. I., (2011), "A Study on consumers' attitude towards online shopping in China", International Journal of Business and Social Science, vol. 2, no. 22, pp. 122132.

Kanchanatanee, K., Suwanno N., \& Jarernvongrayab, A., (2014), "Effects of attitude toward using, perceived usefulness, perceived ease of use and perceived compatibility on intention to use e-marketing", Journal of Management Research, vol. 6, no. 3, pp. 1-13.

Katawetawaraks, C., \& Wang, C. L., (2011), "Online shopper behaviour: Influences of online shopping decision”, Asian Journal of Business Research, vol. 1, no. 2, pp. 66 -74.

Kim, S., Lee, K. H., Hwang, H., \& Yoo, S., (2016), "Analysis of the factors influencing healthcare professionals' adoption of mobile electronic medical record (EMR) using the unified theory of acceptance and use of technology (UTAUT) in a tertiary hospital", BMC Medical Informatics and Decision Making, vol. 16, no. 12, pp. 1-12.

Kline, R. B., (2016), Methodology in the social sciences. Principles and practice of structural equation modelling, Guilford Press, New York.

KPMG, (2017), "The truth about online consumers", Retrieved from http://assets.kpmg.co $\mathrm{m} /$ content/dam/kpmg/ xx/pdf/2017/01f

Law, M., Kwok, R., \& Ng, M. C. W., (2016), "An extended online purchase intention model for middle-aged online users", Electronic Commerce Research and Applications, vol. 20, pp. 132-146.

Lee, M. K., Shi, N., Cheung, C. M., Lim, K. H., \& Sia, C., (2011), "Consumer's decision to shop online: The moderating role of positive informational social influence", Information \& Management, vol. 48, pp. 185-191. 
Lee, J. E., \& Yu, C. J. H., (2018), "Effects of price discount on consumers' perceptions of savings, quality, and value for apparel products: Mediating effect of price discount affect", Fashion and Textile, vol. 5, no. 13, pp. 1-10.

Lim, W. M., \& Ting, D. H., (2012), "E-shopping: An analysis of the technology acceptance model", Modern Applied Science, vol. 6, no. 4, pp. 49-62.

Mapiye Dube, F., Asiedu, R., \& Phiri, A., (2018), "Factors affecting online shopping behaviour of international college students in China", International Journal of Recent Trends in Engineering and Research, vol. 4, no. 12, pp. 18-29.

McLean, G., Osei-Frimpon, K., Wilson, A., \& Pitardi, V., (2020), "How live chat assistants drive travel consumers' attitudes, trust, and purchase intentions: The role of human touch", International Journal of Contemporary Hospitality Management, vol. 32, no. 5, pp. 1795-1812.

McSporran, A. J., \& Cho, Y. C., (2017), “Analysing the determinants of attitude, behaviour, and satisfaction on imported products: Implications for the growing food and beverage industry", Journal of Service Science, vol. 10, no. 1, pp. 13-30.

Miao, D., Lu, J., \& Xie, G., (2017), "Listing-oriented logistics service strategy: A new choice for large transactional online shopping websites", Journal of Service Science and Management, vol. 10, no. 1, pp. 1207-1212.

Michaud-Trévina, A., \& Stenger, T., (2014), "Toward a conceptualization of the online shopping experience", Journal of Retailing and Consumer Services, vol. 21, pp. 314 326.

Nagar, K., (2017), “Assessing the impact of online retailer models on consumer's attitude and purchase intentions", IIM Kozhikode Society \& Management Review, vol. 7, no. 1, pp. $1-12$.

NetOwl, (2018), "Monitoring online reviews with sentiment analysis software", Retrieved from https://www.netowl.com/2018/03/09/monitoring-online-reviews-sentiment-analys is- software.

Nguyễn, T. Q., Nguyen, N., Phan, T. T., Bui, L. P., \& Moon, H. C., (2019), "Investigating consumer attitude and intention towards online food purchasing in an emerging economy: An extended TAM Approach", Foods, vol. 8, no. 11, pp. 1-15.

Oduh, M. O., Oduh, M. O., \& Onyia, M. A., (2012), "Understanding the predictors of consumer sentiments: Lessons for inflation targeting prospects in Nigeria", Research Journal of Finance and Accounting, vol. 3, no. 7, pp. 151-161.

Oduh, M. O., Oduh, M. O., \& Ekeocha, P. C., (2012), "The impact of consumer confidence and expectation on consumption in Nigeria: Evidence from panel data", European Journal of Business and Management, vol. 4, no. 9, pp. 86-101.

Pelaez, A., Chen, C. W., \& Chen, Y. X., (2017), "Effects of perceived risk on intention to purchase: A meta-analysis", Journal of Computer Information Systems, vol. 57, no. 1, pp. 73-84.

Phang, I. G., \& Goh, Y. S., (2019), "Offline brand outcomes of Instagram: Do cognitive network and self-congruity matter?", Asian Journal of Business and Accounting, vol. 12, no. 2, pp. 287-314.

Phang, I. G., \& Ming, T., (2018), "Antecedents of consumer attitude towards blogger recommendations and its impact on purchase intention", Asian Journal of Business and Accounting, vol. 11, no. 1, pp. 293-323.

Reza Jalilvand, M., \& Samiei, N., (2012), "The effect of electronic word of mouth on brand image and purchase intention: An empirical study in the automobile industry in Iran", Marketing Intelligence \& Planning, vol. 30, no. 4, pp. 460-476.

Richardson, A. J., (2012), "Paradigms, theory, and management accounting practice: A comment on Parker", Critical Perspectives on Accounting, vol. 23, no. 1, pp. 83-88.

Rose, S., Clarck, M., Samouel, P., \& Hair, N., (2012), "Online customer experience in eretailing: An empirical model of antecedents and outcomes", Journal of Retailing, vol. 88, no. 2, pp. 308-322. 
Sharma, K., Sharma, P., Chouhan, C., Nage, P., \& Arun, J., (2019), "Study on opinion mining and sentiment analysis", International Conference on Innovation and Advance Technologies in Engineering, Atharva College of Engineering, pp. 19-20.

Shayaa, S., Al-Garadi, M. A., Piprani, A. Z., Ashraf, M., \& Sulaiman, A., (2017), "Social media sentiment analysis of consumer purchasing behaviour vs consumer confidence index", Association for Computing Machinery, pp. 32-35.

Singh, A. K., \& Ajmani, A., (2017), "Future of B2C e-commerce (Buyers perspective) in India: An empirical analysis", Asia-Pacific Journal of Management Research and Innovation, vol. 12 , no. $3 \& 4$, pp. 203-216.

Steinke, D. K. F., (2015), "Influence of trust in ambient assisted living technologies", $P h D$ Dissertation.

Suki, N., \& Suki, N., (2011), "User's behaviour towards ubiquitous m-learning", Journal of Distance Education, vol. 12, no. 3, pp. 118-129.

Teh, P. L., Pak, I., Rayson, P., \& Piao, S., (2015), "Exploring fine-grained sentiment values in online product reviews", 2015 IEEE Conference on Open Systems (ICOS).

Ullman, J. B., \& Bentler, P. M., (2003), Structural equation modeling: Handbook of psychology, Allyn \& Bacon, Boston.

Venkatesh, V., Morris, M. G., Davis, G. B., \& Davis, F. D., (2003), "User acceptance of information technology: Toward a unified view", Management Information System Quarterly, vol. 27, no. 3, pp. 425-478.

Venkatesh, V. T., James, Y. L., \& Xu, X., (2012), "Consumer acceptance and use of information technology: Extending the unified theory of acceptance and use of technology", MIS Quarterly, vol. 36, no. 1, pp. 157-178.

Wang, K., Xia, W., \& Zhang, A., (2017), "Should China further expand its high-speed rail network? Consider the low-cost carrier factor", Transportation Research Part A: Policy and Practice, vol. 100, pp. 105-120.

Wang, H. H., Hao, N., Hou, Q., Wetzstein, M. E., \& Wang, Y., (2019), "Is fresh food shopping sticky to retail channels and online platforms? Evidence and implications in the digital era", Agribusinesses International Journal, vol. 35, pp. 6-19.

Wei, Y., Wang, C., Zhu, S., Xue H., \& Shen, F., (2018), "Online purchase intention of fruits: Antecedents in an integrated model based on technology acceptance model and perceived risk theory", Frontiers in Psychology, vol. 9, no. 1521, pp. 1-11.

Wei, Z., Lee, M. Y., \& Shen, H., (2018), "What drives consumers in China to buy clothing online? Application of the technology acceptance model", Journal of Textiles and Fibrous Materials, vol. 1, pp. 1-10.

Winkler, N., (2020), "What is the future of ecommerce? 10 insights on the evolution of an industry", Retrieved from https://www.shopify.com/enterprise/the-future-of-ecomme rce

Xinhua, (2017), "China focus: China's second-tier cities battle for top talent”, Retrieved from http://www.xinhuanet.com/english/2017-10/31/c_136717574.htm

Xinhua, (2018), "Xinhua headlines: Young adults in small cities reshaping China's consumer power", Retrieve from http://www.xinhuanet.com/english/2018-10/09/c_137520567.ht $\mathrm{m}$.

Zhang, Y., Deng, J. Y., \& Xu, Y. X., (2017), "The effect of different price promotion ways on consumers' purchasing intention", American Journal of Industrial and Business Management, vol. 7, pp. 1192-1208.

Zhou, Q., Xia, R., \& Zhang, C., (2016), "Online shopping behaviour study based on multigranularity opinion mining: China vs. America", Cognitive Computation, vol. 8, no. 4, pp. 587-602. 